\title{
Estimating Food Consumption by a Heavily Fished Stock of Zooplanktivorous Coregonus lavaretus
}

\author{
Reiner Eckmann,* Michael Becker, and Myriam Schmid \\ University of Konstanz, Department of Biology, Limnological Institute, D-78457 Konstanz, \\ Germany
}

\begin{abstract}
The food consumption of adult zooplanktivorous Coregonus lavaretus in Lake Constance, Germany, was estimated monthly from May to October 1989 with a bioenergetics model. To achieve fine temporal resolution of lakewide consumption, we scaled the monthly weight increments of fish during the 6-month growing season by the relative weights of the stomach contents of fish sampled around sunset. As a result, the proportion of maximum consumption varied from month to month. When this proportion was held constant, the total consumption estimates were similar but the allocation of consumption to each month differed by up to $30 \%$ between the two scenarios. Bythotrephes longimanus was the most important prey item from June to October. The average daily consumption of B. longimanus amounted to $15.4 \%$ of the standing stock, while that of daphnids Daphnia spp. and Leptodora kindtii was more than an order of magnitude lower. We conclude that adult $C$. lavaretus in Lake Constance may control the population dynamics of $B$. longimanus but not those of other cladocerans.
\end{abstract}

Quantitative estimates of the consumption of zooplankton by fish are essential for evaluating inter- and intraspecific resource competition (Parrish and Margraf 1990; Rudstam et al. 1994), for analyzing top-down control in the pelagic community (Hülsmann and Mehner 1997; Durbin and Durbin 1998), and for implementing complex ecosystem models (Northcote 1988; Gaedke 1998; Straile 1998). In the large, deep lakes of the northern temperate and subarctic zones, where the fish fauna is often predominated by open water zooplanktivores, such estimates are particularly important for obtaining a better understanding of the structure and function of the lakes' pelagic subsystems. As a case study, we used Lake Constance, a large pre-Alpine lake in southern Germany, where an integrated research program has recently provided new insight into the food web structure and trophic relationships in the pelagic domain (Bäuerle and Gaedke 1998). The role of zooplanktivorous fish in the lake's pelagic food web, however, had not yet been quantified. Therefore, we analyzed fish predation pressure on zooplankton in Lake Constance using data from the time period when most of the other food web studies were conducted.

Powan Coregonus lavaretus (generally known as whitefish in Europe) are the predominant zooplanktivores in Lake Constance. They are heavily fished with monofilament gill nets of strictly con-

\footnotetext{
* Corresponding author: reiner.eckmann@uni-konstanz.de
} Received September 8, 2000; accepted March 9, 2002 trolled mesh size and are generally harvested soon after they reach the legal minimum size (Eckmann and Rösch 1998). Only a few studies in which the lakewide food consumption of powan was quantified have been published (Helminen et al. 1990; Rudstam et al. 1994; Tolonen 1999), and none of these dealt with exclusively zooplanktivorous powan. We therefore considered it necessary to explore some of the methodological problems associated with obtaining lakewide estimates for the consumption of zooplankton by powan.

In Lake Constance, powan are intensively exploited with size-selective gill nets. Under these conditions, the fast-growing members of a cohort are removed at younger ages than the slowgrowing members, as Nümann (1959) has shown by detailed back-calculation of growth. Therefore, cohort growth cannot be modeled along one representative growth trajectory but must be split into different trajectories, each of which is representative of a particular subcohort.

Furthermore, monthly powan yields vary considerably across the growing season. As a result, monthly estimates of consumption by powan should not be based on a virtual population analysis that assumes a constant coefficient of fishing mortality. Fortunately, because the commercial fishery in Lake Constance is thoroughly controlled and scientists and fishery wardens regularly monitor the stock, monthly estimates of virtual population size (structured by year-classes) are available.

Taking advantage of this almost unique data set and considering the above-mentioned problems, 
we selected the following aims for our study: (1) to analyze the sensitivity of monthly consumption estimates based on bioenergetics to variations in the input parameters, population size, and fish growth and (2) to assess the potential impact of zooplanktivorous powan predation on their predominant prey species.

\section{Methods}

Study site.-Upper Lake Constance (BodenseeObersee in German) is a large $\left(472 \mathrm{~km}^{2}\right)$, deep (mean depth, $101 \mathrm{~m}$ ), warm monomictic pre-Alpine lake situated on the northern fringe of the European Alps $\left(9^{\circ} 18^{\prime} \mathrm{E}, 47^{\circ} 39^{\prime} \mathrm{N}\right)$. The lake was originally oligotrophic but underwent pronounced eutrophication during the 20th century. Total phosphorus concentration during winter mixis $\left(\mathrm{TP}_{\text {mix }}\right)$ peaked around 1980 at more than $80 \mu \mathrm{g} / \mathrm{L}$, when the lake was considered to be mesotrophic (Bäuerle and Gaedke 1998). As a result of sewage treatment, including partial $\mathrm{P}$ removal, the lake returned to a more oligotrophic state by the end of the 20th century $\left(\mathrm{TP}_{\text {mix }}\right.$ in 2000,14 $\left.\mu \mathrm{g} / \mathrm{L}\right)$.

Powan are the most abundant zooplanktivores in the lake's pelagic zone. The average yearly harvest of powan was $13 \mathrm{~kg} / \mathrm{ha}$ during the last three decades. This value lies within the range of yields (from $<10$ to about $40 \mathrm{~kg} / \mathrm{ha}$ ) of 40 oligotrophic to eutrophic lakes with commercial powan fisheries in Europe and North America (Eckmann 2000). Two powan forms can be distinguished in upper Lake Constance: inshore spawners and pelagic spawners. According to microsatellite analysis, these forms represent distinct gene pools (Douglas et al. 1999). During the growing season, however, both forms coexist as zooplanktivores in the pelagic zone, and fishing regulations are identical for them (Eckmann and Rösch 1998). Powan yields increased from about 300 metric tons annually prior to 1955 to nearly 500 metric tons thereafter. This has been attributed to changes in the lake's trophic state and to the advent of highly efficient monofilament gill nets in the 1950s. Nevertheless, the proportion of powan in the overall fishery yield decreased during the eutrophication process from more than $70 \%$ to less than $40 \%$, while the proportion of Eurasian perch Perca fluviatilis rose. During the last 15 years this trend has reversed. More details on the Lake Constance fishery can be found in Eckmann and Rösch (1998).

Fish sampling.-Powan were sampled weekly from May to October 1989 in the western part of upper Lake Constance with gill nets of 25-, 32-, 38-, 44-, and 50-mm-bar mesh (yarn diameter, 0.12 $\mathrm{mm})$. Net panels were randomly combined into one fleet $240 \mathrm{~m}$ long and $6 \mathrm{~m}$ deep, which was suspended with droplines from surface floats. Dropline lengths were frequently modified following the recommendations of professional fishermen in order to obtain high catches during short exposure times. The fleet was set in the pelagic zone from $2 \mathrm{~h}$ before until $1 \mathrm{~h}$ after sunset.

All fish were measured, weighed, and sexed, and fish selected randomly from all size-groups were aged by scale reading. For consumption analyses, only age- 2 and age-3 fish (total length, 29-41.5 $\mathrm{cm}$; wet weight, 220-630 g) were considered, which accounted for $82 \%$ of the total catch in terms of numbers. Stomachs from 15 to 20 fish per sample were preserved in a $4 \%$ solution of formalin. In total, 627 fish were sampled for stomach analysis. Additionally, the stomachs from 9 to 17 fish per sample (mean, 13.3 fish) were removed and stored on ice for gravimetric determination of stomach fullness.

Diet analyses.-The contents of the formalinpreserved stomachs were quantitatively flushed into a zooplankton counting chamber. Under a dissecting microscope, prey items were identified to species and counted. For Daphnia galeata and D. hyalina, two size-classes were distinguished $(\leq 1.5$ $\mathrm{mm}$ and $>1.5 \mathrm{~mm}$ ), while for Leptodora kindtii and Bythotrephes longimanus randomly chosen specimens were measured. For each sample, fish stomach contents were expressed as mean percentage composition by number (Becker 1992). These values were then converted to percentage composition by biomass by means of length-dry weight relationships (Geller and Muller 1985; Hälbich 1997) and average dry matter content values (Hanson et al. 1997). The mean length of ingested daphnids was $1.9 \mathrm{~mm}$ for both species, which corresponded to $40 \mu \mathrm{g}$ dry weight and $364 \mu \mathrm{g}$ wet weight at $11 \%$ dry matter content. The values for L. kindtii were $5.4 \mathrm{~mm}, 37 \mu \mathrm{g}$ dry weight, and 925 $\mu \mathrm{g}$ wet weight at $4 \%$ dry matter content, and those for $B$. longimanus were $2.1 \mathrm{~mm}, 56 \mu \mathrm{g}$ dry weight, and $509 \mu \mathrm{g}$ wet weight at $11 \%$ dry matter content.

Zooplankton samples.-Zooplankton were collected with a Clark-Bumpus sampler once per fishing day immediately after the gill nets had been set, that is, $2 \mathrm{~h}$ before sunset. The upper $20 \mathrm{~m}$ of water were sampled by two vertical tows of $10 \mathrm{~m}$. Samples were preserved in sugar-formalin and evaluated in the same way as stomach contents. Zooplankton abundance was expressed as individuals per square meter. Finally, a weighted mean abundance was calculated for each month. 
Temperature.-Temperature profiles were taken with a temperature-depth probe once per fishing day. Data were registered at $1-\mathrm{m}$ intervals in the upper $10 \mathrm{~m}$ of water and at 5 -m intervals at greater depths. From these profiles, the average temperature of the depth layer fished by the gill nets was calculated. Several day - night echo surveys during 1989 showed that the pelagic powan did not migrate vertically to any detectable extent during the growing season (our unpublished data). Thus, the overall mean temperature experienced by powan from the beginning of May until the end of October was $12.8^{\circ} \mathrm{C}$ (range, $8.8-16.7^{\circ} \mathrm{C}$ ), without any seasonal trend.

Growth.-In the mesotrophic upper Lake Constance, powan grew mainly from May to October (Hartmann and Quoss 1982); although this was about 2 months longer than under the previous oligotrophic conditions, we have no indication so far that the growing season has become shorter since nutrient reduction began. We therefore assumed that the entire annual growth occurs between May 1 and October 31.

The mean lengths of powan (males and females combined) 2, 3, and 4 years old were 27.6, 33.8, and $36.7 \mathrm{~cm}$ for 1992-1995 (C. Ruhlé, Wildlife and Fishery Administration, St. Gallen, Switzerland, personal communication). These values were converted to approximately 190, 350, and $450 \mathrm{~g}$ wet weight, respectively, by means of a length - weight relationship based on our 1989 powan samples $\left(65-620 \mathrm{~g}, n=622, r^{2}=0.91\right)$.

The cohorts are normally fished out from the 3 rd to the 6th year of life, the faster-growing members at younger ages than the slower-growing members (Nümann 1959). Weight at harvest increased slightly during the 1989 growing season. Age-2 fish weighed 290, 340, 350, 360, 390, and $380 \mathrm{~g}$ at harvest in the months from May to October 1989, while age-3 fish weighed 400, 410, $425,435,450$, and $450 \mathrm{~g}$, respectively. For simplicity, we assumed that the weight of age-2 fish that were harvested in October had increased from 190 to $380 \mathrm{~g}$ over the 6 months and that that of age-3 fish had increased from 350 to $450 \mathrm{~g}$.

Since we had no precise data on monthly weight gain for the different age-classes of powan in Lake Constance, we needed to model their growth trajectory during the growing season. We used stomach fullness values from the fish sampled around sunset as proxies for food consumption and hence growth. Stomach fullness, however, may not always be directly related to growth, and particularly so if food quality and digestibility differ consid-
TABLE 1.-Mean monthly stomach fullness of powan (generally known as whitefish in Europe) in Lake Constance, Germany (stomach content wet weight as a percentage of fish wet weight based on samples collected at sunset) during the 1989 growing season. The total yearly growth (190 $\mathrm{g}$ for age-2 fish and $100 \mathrm{~g}$ for age-3 fish) was allocated to the 6 months of the growing season according to stomach fullness.

\begin{tabular}{lccc}
\hline & $\begin{array}{c}\text { Stomach } \\
\text { fullness } \\
(\%)\end{array}$ & \multicolumn{2}{c}{ Monthly weight gain $(\mathrm{g})$} \\
\cline { 3 - 4 } Month & 1.10 & 52 & Age-2 fish \\
\hline May & 0.81 & 38 & 27 \\
Jun & 0.72 & 34 & 20 \\
Jul & 0.66 & 31 & 18 \\
Aug & 0.47 & 23 & 17 \\
Sep & 0.25 & 12 & 12 \\
Oct & & & 6 \\
\hline
\end{tabular}

erably across time. In spite of this uncertainty, and taking into account the strong seasonal variation of zooplankton abundance in Lake Constance (Straile and Geller 1998), we considered it more appropriate to scale monthly growth by stomach fullness than to assume linear growth over the entire growing season.

The stomach fullness index decreased from $1.1 \%$ (wet weight basis) in May to $0.25 \%$ in October (Table 1). When we scaled weight gain over the growing season by these values, the monthly growth of age- 2 fish decreased from $52 \mathrm{~g}$ in May to $12 \mathrm{~g}$ in October and that of age-3 fish from 27 to $6 \mathrm{~g}$ (Table 1). The growth trajectories of those fish that were fished out earlier in the year were calculated backwards, starting with the weight at catch and subtracting the monthly weight increments that had been established for the fish harvested in October. As a result, growth curves for the subcohorts of age- 2 and age- 3 fish, which were fished in different months, run parallel (Figure 1).

In addition to the fish that were harvested during 1989, other fish in the lake also consumed plankton that year. Almost all age-3 fish that were not harvested in 1989 were fished out at age 4 in 1990. As their weighted mean weight at capture $(427 \mathrm{~g})$ was only $2 \mathrm{~g}$ higher in 1990 than in 1989, we assumed that these fish had grown from 190 to 380 $\mathrm{g}$ in 1989. Part of the 1987 year-class was caught in 1990 at a weighted mean weight of $410 \mathrm{~g}$, and we assumed that these fish had also grown from 190 to $380 \mathrm{~g}$ in 1989 . The monthly growth of these groups of fish was modeled according to the growth of the cohorts fished in October 1989. Other subcohorts of the 1987 year-class were fished in 1991 and 1992 at average weights of 410 and $414 \mathrm{~g}$. These most slowly growing members of the 


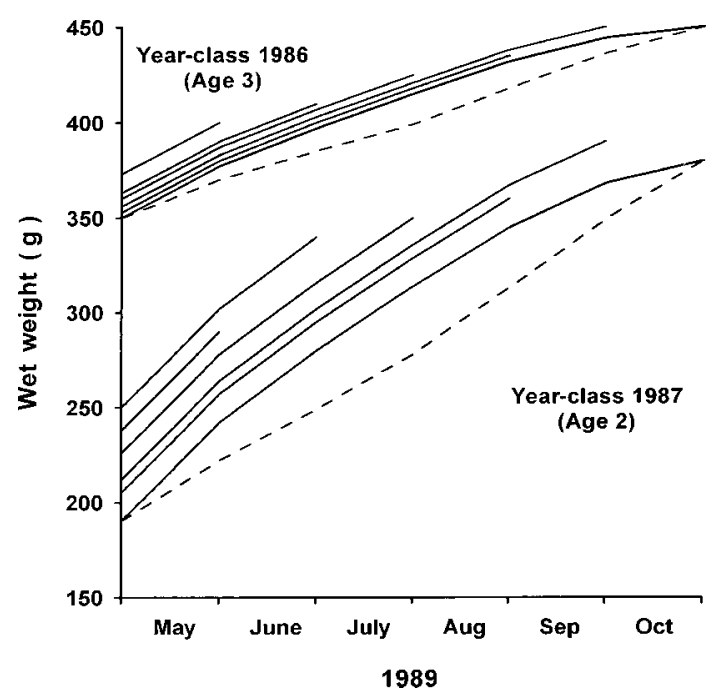

FIGURE 1.-Monthly growth (solid lines) of adult powan (generally known as whitefish in Europe) subcohorts from the 1986 and 1987 year-classes during the 1989 growing season in upper Lake Constance, Germany. The monthly weight gain for the age- 2 subcohort that was fished out in October (the October cohort) was scaled according to relative stomach content weight. Monthly growth for all other age-2 subcohorts was backcalculated from the weight at harvest by subtracting the monthly weight gains of the October cohort. The same procedure was followed for age- 3 fish. The dashed lines show growth curves calculated with a coefficient of maximum consumption that was held constant from May to October.

1987 year-class probably weighed less than $200 \mathrm{~g}$ in 1989. Fish of this size have a different food spectrum from larger individuals (Becker 1992), but our samples were too small to describe their diet quantitatively. These fish and the 1988 cohort (age 1 in 1989) were excluded from the zooplankton consumption estimates, which systematically biased our data towards low values.

Population size.-The age composition of commercial powan catches is regularly assessed through internationally coordinated test fishing with gill nets of legal mesh size. Additionally, professional fishermen report monthly on commercial yields in terms of total weight. From these data, the number of fish of a particular year-class that are removed from the lake can be calculated month by month until the cohort is fished out. By cumulative addition of the yields in terms of numbers, starting with the last harvest of a cohort and moving back until the cohort was first recruited into the fishery, monthly estimates of virtual population size are obtained. These data, however, do not account for losses to natural mortality. We assumed that the instantaneous rate of natural mortality is constant for powan of age 2 and older and chose a value of $0.2 /$ year based on published estimates of natural mortality (Meng et al. 1986; Reckahn 1992; Mills et al. 1998). Virtual population estimates were then corrected for mortality losses by assuming (1) that the number of fish decreased exponentially during 1 month due to natural mortality and (2) that the fish that were harvested were all removed at the end of that month.

These population estimates are only available for the pelagic-spawning powan. Both the pelagic- and inshore-spawning forms are, however, fished with identical mesh sizes, so that their weight at capture is similar. Since we had no indication that the growth rates of the two forms differ, we assumed that their age compositions were the same. In 1989, the harvest in terms of weight of inshore-spawning powan was $36 \%$ of that of the pelagic-spawning form, so we obtained a population estimate for both forms combined by adding $36 \%$ to the estimate for the pelagicspawning form.

Consumption estimates.-We used the Wisconsin bioenergetics model (Hanson et al. 1997) to estimate zooplankton consumption by powan. The physiological parameter values for the generalized coregonid model are largely based on benthivorous bloater $C$. hoyi but also on lake whitefish $C$. clupeaformis, while the weight exponent of the consumption equation has been derived from experiments on the consumption of zooplankton by Lake Constance powan (Rudstam et al. 1994). We used the default parameter values of the Wisconsin model since the model has not yet been parameterized for exclusively zooplanktivorous powan (Helminen et al. 1990; Tolonen 1999). Energy content was held constant for predators $(13,060 \mathrm{~J} / \mathrm{g}$ wet mass) and prey $(2,513 \mathrm{~J} / \mathrm{g}$ wet mass for both daphnid species and B. longimanus, $949 \mathrm{~J} / \mathrm{g}$ wet mass for L. kindtii) during the simulation period since data on seasonal energy content were not available. Lake powan are fully mature at age 2, but the gonadosomatic index of females is less than $10 \%$ until late September (Rösch 2000). Therefore, the assumption that powan energy content remains constant seems reasonable for all months except October. For this month we probably underestimated consumption due to the increased energy content of maturing females. However, Bartell et al. (1986) have shown that bioenergetics models 
TABLE 2.-Mean numbers of the four predominant prey species in the stomachs of adult powan from upper Lake Constance during the 1989 growing season. Fish were sampled around sunset and 15-20 stomachs were analyzed per sample.

\begin{tabular}{lrrrr}
\hline Date & $\begin{array}{c}\text { Daphnia } \\
\text { hyalina }\end{array}$ & $\begin{array}{c}\text { Daphnia } \\
\text { galeata }\end{array}$ & $\begin{array}{c}\text { Leptodora } \\
\text { kindtii }\end{array}$ & $\begin{array}{c}\text { Bythotrephes } \\
\text { longimanus }\end{array}$ \\
\hline May 2 & 5,155 & 14 & 1 & 23 \\
May 9 & 4,087 & 37 & 5 & 8 \\
May 16 & 7,829 & 120 & 8 & 87 \\
May 22 & 1,904 & 123 & 12 & 89 \\
Jun 8 & 162 & 2,056 & 32 & 465 \\
Jun 12 & 0 & 110 & 7 & 3,012 \\
Jun 20 & 32 & 681 & 480 & 1,716 \\
Jul 3 & 5 & 814 & 500 & 1,358 \\
Jul 10 & 7 & 883 & 316 & 1,016 \\
Jul 17 & 2,314 & 180 & 44 & 417 \\
Jul 24 & 14 & 340 & 109 & 2,460 \\
Aug 9 & 3 & 69 & 55 & 1,860 \\
Aug 14 & 11 & 844 & 81 & 2,755 \\
Aug 21 & 1 & 332 & 53 & 2,311 \\
Aug 29 & 7 & 869 & 3 & 205 \\
Sep 4 & 70 & 169 & 21 & 833 \\
Sep 11 & 1 & 110 & 20 & 3,254 \\
Sep 18 & 116 & 899 & 17 & 746 \\
Sep 25 & 25 & 60 & 19 & 210 \\
Oct 2 & 8 & 40 & 5 & 514 \\
Oct 17 & 198 & 90 & 36 & 361 \\
Oct 25 & 143 & 17 & 29 & 181 \\
\hline
\end{tabular}

are not highly sensitive to changes in energy densities.

For each subcohort of age- 2 and age- 3 fish, (i.e., those fish that were harvested in different months in 1989), we obtained monthly consumption estimates based on their weight increment (Figure 1) and diet composition (Table 2) during that month. Similarly, consumption was estimated for age- 2 and age- 3 fish that were harvested in 1990. The total consumption of zooplankton was calculated by summing consumption across subcohorts and age-classes for each month from May to October.

Sensitivity analyses of the bioenergetics model.To evaluate the sensitivity of the bioenergetics consumption estimates to variations in the input parameters, temperature, population size, and fish growth, we performed three sensitivity analyses in

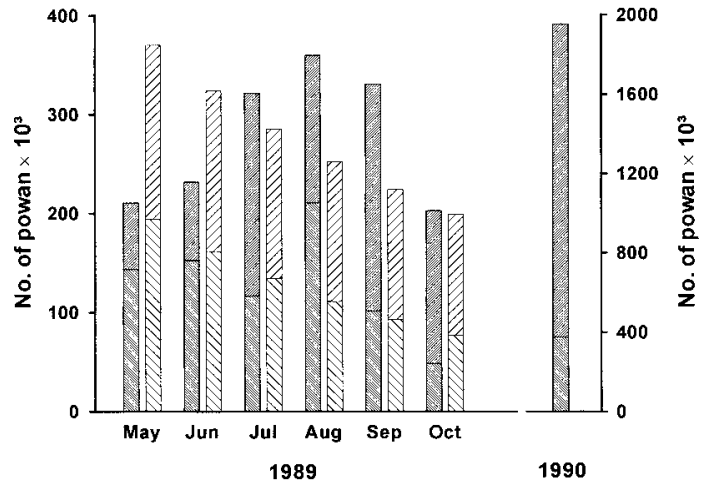

FIGURE 2.-Powan harvests in upper Lake Constance from the 1986 (backward slashes) and 1987 (forward slashes) year-classes during the 1989 growing season (left scale) and in 1990 (right scale). Pelagic- and inshore-spawning powan are combined. Values indicated by the first bar for each month and that for 1990 were calculated from the original monthly harvest data; those indicated by the second bar for each month were calculated with a constant coefficient of fishing mortality from May to October 1989.

addition to obtaining our baseline estimate of zooplankton consumption. First, we calculated total zooplankton consumption for a powan growing from 190 to $380 \mathrm{~g}$ in 6 months at the actual temperatures at the fishing depths, at a constant temperature of $12^{\circ} \mathrm{C}$, and at an overall mean temperature at the fishing depths of $12.8^{\circ} \mathrm{C}$. In all cases, the fish's diet was the same, that is, it corresponded to the stomach contents from the sunset samples. Second, we created a data set in which the total harvest during the 6-month growing season was allocated to the different months according to a coefficient of fishing mortality that was held constant across time (Figure 2). And third, we modeled fish growth with a constant proportion of maximum consumption ( $p$-value) throughout the growing season, that is, without scaling monthly weight gain to stomach fullness. Thus, the monthly weight increments ranged from 26 to $35 \mathrm{~g}$ ( $p$-value $=$ 0.345 ) for age- 2 fish and from 12 to $20 \mathrm{~g}$ ( $p$-value $=0.267$ ) for age- 3 fish (Figure 1 ).

TABLE 3.-Absolute (metric tons wet weight) and percentage contributions of the 1986 and 1987 year-classes to the total monthly zooplankton consumption by adult powan in upper Lake Constance during the 1989 growing season.

\begin{tabular}{|c|c|c|c|c|c|c|c|c|c|c|}
\hline \multirow{2}{*}{$\begin{array}{c}\text { Year-class/year } \\
\text { of harvest }\end{array}$} & \multicolumn{2}{|c|}{ May } & \multicolumn{2}{|c|}{ Jun } & \multicolumn{2}{|c|}{ Jul } & \multicolumn{2}{|c|}{ Aug } & \multicolumn{2}{|c|}{ Sep } \\
\hline & Tons & $\%$ & Tons & $\%$ & Tons & $\%$ & Tons & $\%$ & Tons & $\%$ \\
\hline $1986 / 1989$ & 564 & 19.3 & 464 & 17.5 & 362 & 14.6 & 261 & 12.5 & 112 & 6.7 \\
\hline $1987 / 1989$ & 780 & 26.6 & 692 & 26.0 & 628 & 25.2 & 437 & 20.9 & 301 & 18.1 \\
\hline $1986+1987 / 1990$ & 1,586 & 54.1 & 1,504 & 56.5 & 1,498 & 60.2 & 1,390 & 66.6 & 1,253 & 75.2 \\
\hline Total & 2,930 & & 2,660 & & 2,488 & & 2,088 & & 1,666 & \\
\hline
\end{tabular}




\section{Results}

\section{Diet}

The powan in Lake Constance consumed D. galeata, D. hyalina, L. kindtii, and B. longimanus in varying proportions throughout the growing season (Table 2). The number of cyclopoid copepods in the fish's diet decreased from $10 \%$ on May 2 to $2.8 \%$ on May 22 and was insignificant thereafter. Eudiaptomus spp. and Bosmina spp. were only found occasionally. Hence, copepods and Bosmina were excluded from consumption estimates.

$D$. hyalina dominated the powan diet in May, were almost absent from the stomachs from June to September, and formed an increasing proportion of the diet in October (Table 2). The only exception to this pattern was observed on July 17 , when $D$. hyalina accounted for almost $73 \%$ of the average stomach contents in terms of biomass. Apart from this unique event, B. longimanus was by far the most important food of powan from June to early October, followed by D. galeata and to a lesser extent L. kindtii.

\section{Population Size}

The 1986 and 1987 year-classes accounted for more than $99 \%$ (in terms of number) of all pelagicspawning powan harvested in 1989. Taking both forms together, 802,500 fish from the 1986 yearclass and 970,900 fish from the 1987 year-class were nominally harvested from May to December 1989. In 1990, 374,000 fish from the 1986 yearclass and 1,579,000 from the 1987 year-class were harvested. The 1989 monthly harvest values are depicted in Figure 2, which also shows the monthly harvest values that were calculated with a constant coefficient of fishing mortality from May to October 1989.

\section{Zooplankton Consumption}

According to bioenergetics estimates, age- 2 and older powan consumed 2,930 metric tons of freshweight zooplankton in May 1989 and consumption decreased steadily to 1,306 metric tons in October

TABLE 3.-Extended.

\begin{tabular}{lrrr}
\hline \multirow{2}{*}{$\begin{array}{c}\text { Year-class/year } \\
\text { of harvest }\end{array}$} & \multicolumn{2}{c}{ Oct } & \multirow{2}{*}{$\begin{array}{l}\text { Total } \\
\text { tons }\end{array}$} \\
\cline { 2 - 3 } & Tons & $\%$ & \\
\hline $1986 / 1989$ & 48 & 3.7 & 1,811 \\
$1987 / 1989$ & 137 & 10.5 & 2,975 \\
$1986+1987 / 1990$ & 1,121 & 85.8 & 8,352 \\
Total & 1,306 & & 13,138 \\
\hline
\end{tabular}

(Table 3). The contribution of age- 2 and age- 3 fish to overall consumption decreased from $26.6 \%$ to $10.5 \%$ and from $19.3 \%$ to $3.7 \%$, respectively, as these age-groups were fished out during the year, while the contribution of fish that were not harvested until the following year increased from $54.1 \%$ to $85.8 \%$.

In May, when the abundance of B. longimanus had just started to increase, the contribution in terms of biomass of this species to the powan diet was low $(4.3 \%)$, while $D$. hyalina accounted for $86.4 \%$ of powan consumption of zooplankton. From June to October, however, B. longimanus accounted for $51-75 \%$ of their monthly consumption. B. longimanus was thus by far the most important food of adult powan throughout the growing season.

The daily consumption of zooplankton by adult powan is compared with monthly averages of zooplankton standing stock in Table 4 . The overall mean consumption of B. longimanus was $15.4 \%$ of the standing stock, while that of L. kindtii and both daphnid species was more than an order of magnitude lower. Since these data suggest that adult powan in upper Lake Constance control the population dynamics of $B$. longimanus but not of daphnids, our sensitivity analyses focused on the consumption of the former.

The influence of different temperature scenarios on total consumption estimates was weak. When we input the actual temperatures at the fishing depths, total consumption was $3,808 \mathrm{~g}$ wet weight; at a constant temperature of $12^{\circ} \mathrm{C}$ it was $3,712 \mathrm{~g}$, and at an overall mean temperature at the fishing depths of $12.8^{\circ} \mathrm{C}$ it was $3,789 \mathrm{~g}$. The contribution of different zooplankton species to total consumption differed by a maximum of $1.4 \%$ between the constant- and fluctuating-temperature scenarios, and the allocation of consumption to the 6 months of the main growing season differed by a maximum of $3.0 \%$. The second alternative scenario, in which powan were removed from the lake according to a constant coefficient of fishing mortality (Figure 2), underestimated the consumption of $B$. longimanus only slightly as compared with the baseline calculation (Table 5). In the third scenario, however, in which powan growth was modeled with a constant $p$-value across the 6-month growing season, there was considerable deviation from the baseline values (Table 5).

\section{Discussion}

The bioenergetic model parameters that we used were based on benthivorous bloater and lake 
TABLE 4.-Average zooplankton standing stock $\left(10^{3}\right.$ individuals $\left./ \mathrm{m}^{2}\right)$ from 0 to $20 \mathrm{~m}$ depth in upper Lake Constance and daily consumption by adult powan as a percentage of the average standing stock during the 1989 growing season. Abbreviations are as follows: B.1. = Bythotrephes longimanus; D.g. = Daphnia galeata; D.h. = Daphnia hyalina; and L.k. = Leptodora kindtii.

\begin{tabular}{|c|c|c|c|c|c|c|c|c|}
\hline \multirow[b]{2}{*}{ Month } & \multicolumn{4}{|c|}{ Zooplankton standing stock } & \multicolumn{4}{|c|}{ Consumption of standing stock $(\%)$} \\
\hline & B.1. & D.g. & D.h. & L.k. & B.1. & D.g. & D.h. & L.k. \\
\hline May & 0 & 139.9 & 151.9 & 0.1 & & $<0.1$ & 0.3 & 1.3 \\
\hline Jun & 3.6 & 62.8 & 54.4 & 2.6 & 5.2 & 0.2 & 0.1 & 1.2 \\
\hline Jul & 1.5 & 55.2 & 12.0 & 12.8 & 12.2 & 0.1 & 0.6 & 0.2 \\
\hline Aug & 2.4 & 84.0 & 4.1 & 1.1 & 8.7 & 0.1 & $<0.1$ & 0.6 \\
\hline Sep & 1.4 & 20.7 & 3.0 & 0.5 & 12.1 & 0.3 & 0.4 & 1.1 \\
\hline Oct & 0.3 & 2.3 & 3.7 & 0.5 & 38.6 & 0.7 & 1.2 & 1.8 \\
\hline Average & & & & & 15.4 & 0.2 & 0.4 & 1.0 \\
\hline
\end{tabular}

whitefish as well as Lake Constance powan (Rudstam et al. 1994) and may therefore not be entirely appropriate for purely zooplanktivorous powan. However, since bioenergetic model parameters have not been estimated specifically for zooplanktivorous powan (Helminen et al. 1990; Tolonen 1999), we relied on the generalized coregonid model (Hanson et al. 1997).

We observed that the different temperature scenarios had only a slight influence on total consumption, the contribution of the main prey species to total consumption, and the allocation of consumption to the 6 months of the growing season. Since temperature fluctuations were random and did not show any seasonal trend, we considered it appropriate to run all simulations at the overall mean temperature at the fishing depths of $12.8^{\circ} \mathrm{C}$.

For analyzing the impact of zooplanktivorous fish on their prey, fine temporal resolution of prey population dynamics and fish consumption is required. Estimates of the latter two essentially depend on reliable estimates of population size and growth rate, both of which are structured by sizeclasses. When weight-at-age data are available at sufficiently short time intervals, consumption can be estimated for each growth interval (e.g., Helminen et al. 1990). In this case, the $p$-value can be adjusted to the observed weight gain for each time interval. When only year-end weight data are available, consumption estimates are generally obtained with the $p$-value held constant across time (e.g., Rudstam et al. 1994). Even though overall consumption will be correctly estimated in this way, the allocation of consumption to shorter time intervals might be incorrect. In our case, weight at harvest was fairly well known, but precise data on weight gain across time were lacking. We assumed that the sunset stomach content weight, which represents the maximum stomach content weight observed during each $24-\mathrm{h}$ period, can be taken as a proxy for food consumption. Furthermore, since powan were assumed to experience the same temperature throughout the growing season, stomach content weight can be used as an indication of growth rate. Under these assumptions, the total zooplankton consumption of an age-2 powan growing from 190 to $380 \mathrm{~g}$ over 6 months was $3,956 \mathrm{~g}$. If the $p$-value was held constant at 0.345 , the total consumption was $3,775 \mathrm{~g}$. For an age-3 powan growing from 350 to $450 \mathrm{~g}$, the respective values were 3,828 and $3,756 \mathrm{~g} \mathrm{(} p$ -

TABLE 5.-Daily consumption of Bythotrephes longimanus by adult powan during the 1989 growing season estimated according to three different scenarios and $B$. longimanus mortality. All values are given as individuals $\cdot \mathrm{m}^{-2} \cdot \mathrm{d}^{-1} \mathrm{except}$ those in parentheses, which are percentages of baseline consumption. The baseline scenario was based on monthly harvest figures and monthly growth rates scaled by stomach content weight. In the constant- $F$ scenario, monthly harvests were calculated with a constant coefficient of fishing mortality. In the constant $p$-value scenario, the proportion of maximum consumption was held constant. For further details, see text.

\begin{tabular}{lllllll}
\hline \multicolumn{1}{c}{ Variable } & May & Jun & Jul & Aug & Sep & Oct \\
\hline Consumption & & & & & & \\
$\quad$ Baseline & 17 & 189 & 183 & 209 & 170 & 116 \\
Constant $F$ & $18(101)$ & $181(96)$ & $170(93)$ & $194(93)$ & $163(96)$ & $116(100)$ \\
$\quad$ Constant $p$-value & $13(76)$ & $156(83)$ & $162(89)$ & $210(100)$ & $196(115)$ & $150(130)$ \\
$\begin{array}{l}\text { B. longimanus } \\
\text { mortality rate }\end{array}$ & 307 & 566 & 157 & 142 & 47 & 89 \\
\hline
\end{tabular}


value $=0.267$ ). The total consumption estimates thus matched fairly well. The allocation of consumption to the 6 months of the main growing season, however, differed considerably between the two scenarios. When we compared the monthly consumption estimates for the entire adult powan population, the constant- $p$-value scenario underestimated our baseline model data by $24 \%$ in May and overestimated them by $30 \%$ in October (Table 5). As long as no better estimates of powan growth across time are available, we feel that our baseline approach is more realistic than simply adopting a constant $p$-value for the entire growing season.

As with the growth rate, size-structured data on fish population size are crucial for analyzing the predation impact of fish on zooplankton. When estimates of fish population size are only available for certain points in time or harvest data are integrated over longer periods (e.g., one fishing season), population sizes can be calculated by backextrapolation across time, adapting the coefficients of natural and fishing mortality accordingly (Helminen et al. 1990). Because monthly harvest data are available for the Lake Constance powan fishery, the virtual stock size can easily be calculated month by month. However, the magnitude of natural mortality is unknown. When we incorporated a natural mortality coefficient of $0.0167 /$ month, the estimates of total zooplankton consumption increased by amounts ranging from 3\% in October to $9 \%$ in May. We included this estimate of natural mortality in our baseline calculation. Next, we analyzed the importance of explicitly considering monthly harvest data instead of using a constant coefficient of fishing mortality. The latter scenario underestimated our baseline values only slightly (Table 5). These small deviations will, however, eventually increase owing to the errors that are introduced by other parameter estimates. We therefore suggest that the best available estimates of stock size across time should be used for consumption estimates.

A major source of uncertainty lies in the consumption estimates for fish that were not recruited into the fishery in 1989 . The monthly consumption of these fish ranged from $54.1 \%$ to $85.8 \%$ of the total consumption by the adult powan stock. Any error in either the abundance or growth estimates for the prerecruits will have a considerable impact on the overall consumption estimates. For a more refined, temporally explicit analysis of powanzooplankton interactions, a detailed study of the prerecruits' diet and growth is necessary. It should be noted, though, that the 1987 year-class, which accounted for more than $80 \%$ of the prerecruits of age 2 and older in 1989, was a very strong one. The virtual size of this year-class was $1.8 \times 10^{6}$ individuals (natural mortality excluded), while the average virtual year-class strength for the years 1962-1988 was $0.9 \times 10^{6}$ individuals. If we had assumed that the 1987 cohort was an average one and set the number of prerecruits to $50 \%$ of the observed value, their contribution to the overall consumption of zooplankton would still have ranged from $37 \%$ in May to $75 \%$ in October. Therefore, even under this scenario better knowledge of the prerecruits' growth is deemed necessary.

The role of B. longimanus as an important prey for planktivorous fish, including coregonids, has been demonstrated repeatedly (Giussani 1974; Nilsson 1974; Langeland 1978; Fitzmaurice 1979; Mookerji et al. 1998), but quantitative estimates of $B$. longimanus consumption by powan have not been reported so far. Our monthly estimates agree fairly well with independently derived estimates of $B$. longimanus mortality rates (Table 4) calculated according to Paloheimo (1974) and Saunders et al. (1999) (D. Straile, Limnological Institute, University of Konstanz, personal communication). We do not argue that this is final proof for the validity of our approach, however, since both our fish consumption and zooplankton mortality rate calculations are constrained by certain assumptions and uncertainties in the parameter estimates. Nonetheless, fine temporal resolution of fish consumption does provide the opportunity to analyze fish-zooplankton interactions in a very detailed fashion.

We conclude from our analyses that adult powan in upper Lake Constance may control the population dynamics of $B$. longimanus from June to October but not those of daphnids and L. kindtii (Table 4). Since this result is based on monthly consumption estimates, we are confident that our conclusion is valid for the entire growing season. In particular, adult powan apparently did not contribute to the collapse of the $D$. galeata stock at the end of the clearwater phase in June, since the daily consumption by powan amounted to only $0.2 \%$ of the standing stock (Table 4 ). A more detailed analysis of $B$. longimanus population dynamics will probably improve our understanding of the top-down control of this carnivorous cladoceran by planktivorous powan.

\section{Acknowledgments}

Alfred Sulger performed all fishing operations and helped in sample processing; we thank him 
for his dedication and patience. We also appreciate the valuable comments by Roland Rösch, Dietmar Straile, and three reviewers. Mary Morris corrected the English of an earlier version. This study was supported by Deutsche Forschungsgemeinschaft within the collaborative research centers SFB 248, Cycling of Matter in Lake Constance, and SFB 454, Littoral of Lake Constance.

\section{References}

Bartell, S. M., J. E. Breck, R. H. Gardner, and A. L. Brenkert. 1986. Individual parameter perturbation and error analysis of fish bioenergetic models. Canadian Journal of Fisheries and Aquatic Sciences 43:160-168.

Bäuerle, E., and U. Gaedke, editors. 1998. Lake Constance: characterization of an ecosystem in transition. Archiv für Hydrobiologie, Advances in Limnology 53, Stuttgart, Germany.

Becker, M. 1992. Ingestions- und Selektionsverhalten adulter Felchen (Coregonus lavaretus) des Bodensees: saisonale und diurnale Variabilität. [Food ingestion and selection of adult powan Coregonus lavaretus in Lake Constance: seasonal and diel variability.] Doctoral dissertation. University of Konstanz, Konstanz, Germany.

Douglas, M. R., P. C. Brunner, and L. Bernatchez. 1999. Do assemblages of Coregonus (Teleostei: Salmoniformes) in the Central Alpine region of Europe represent species flocks? Molecular Ecology 8:589603.

Durbin, A. G., and E. G. Durbin. 1998. Effects of menhaden predation on plankton populations in Narragansett Bay, Rhode Island. Estuaries 21:449-465.

Eckmann, R. 2000. Der Einfluß der Trophie auf Wachstum und Ertrag von Coregonen. [The influence of trophic state on the growth and yield of coregonids.] Münchener Beiträge zur Abwasser-, Fischerei- und Flußbiologie 53:425-437.

Eckmann, R., and R. Rösch. 1998. Lake Constance fisheries and fish ecology. Pages 285-301 in E. Bäuerle and U. Gaedke, editors. Lake Constance: characterization of an ecosystem in transition. Archiv für Hydrobiologie, Advances in Limnology 53, Stuttgart, Germany.

Fitzmaurice, P. 1979. Selective predation on Cladocera by brown trout Salmo trutta. Journal of Fish Biology 15:521-526.

Gaedke, U. 1998. The response of the pelagic food web to re-oligotrophication of a large and deep lake (L. Constance): evidence for scale-dependent hierarchical patterns? Pages 317-333 in E. Bäuerle and U. Gaedke, editors. Lake Constance: characterization of an ecosystem in transition. Archiv für Hydrobiologie, Advances in Limnology 53, Stuttgart, Germany.

Geller, W., and H. Müller. 1985. Seasonal variability in the relationship between body-length and individual dry weight as related to food abundance and clutch size in two coexisting Daphnia species. Journal of Plankton Research 7:1-18.
Giussani, G. 1974. Planctofagia selettiva del coregone "Bondella" (Coregonus sp.) del Lago Maggiore. [Selective planktivory by the coregonid Bondella (Coregonus spp.) in Lake Maggiore.] Memorie dell'Istituto Italiano di Idrobiologia 31:181-203.

Hälbich, A. 1997. Populationsdynamik von Bythotrephes longimanus (Leydig) und Leptodora kindtii (Focke) im Bodensee und mögliche Mechanismen ihrer Koexistenz. [Population dynamics of Bythotrephes longimanus (Leydig) and Leptodora kindtii (Focke) in Lake Constance and possible mechanisms for their coexistence.] Diploma thesis. University of Konstanz, Konstanz, Germany.

Hanson, P. C., T. B. Johnson, D. E. Schindler, and J. E. Kitchell. 1997. Fish bioenergetics 3.0. University of Wisconsin System, Sea Grant Institute, Center for Limnology, Madison.

Hartmann, J., and H. Quoss. 1982. Längere Wachstumssaison des Felchens (Coregonus lavaretus) in einem eutrophierten See. [Longer growing season for powan Coregonus lavaretus in a eutrophic lake.] Fischwirt 32:68-69.

Helminen, H., J. Sarvala, and A. Hirvonen. 1990. Growth and food consumption of vendace (Coregonus albula [L.]) in Lake Pyhäjärvi, SW Finland: a bioenergetics modeling analysis. Hydrobiologia 200/201:511-522.

Hülsmann, S., and T. Mehner. 1997. Predation by underyearling perch (Perca fluviatilis) on a Daphnia galeata population in a short-term enclosure experiment. Freshwater Biology 38:209-219.

Langeland, A. 1978. Effect of fish (Salvelinus alpinus, arctic char) predation on the zooplankton in ten Norwegian lakes. Verhandlungen der Internationalen Vereinigung für Limnologie 20:2065-2069.

Meng, H. J., R. Müller, and W. Geiger. 1986. Growth, mortality, and yield of stocked coregonid fingerlings identified by microtags. Archiv für Hydrobiologie, Advances in Limnology 22:319-325.

Mills, K. H., B. R. McCulloch, S. M. Chalanchuk, D. J. Allan, and M. P. Stainton. 1998. Growth, size, structure, and annual survival of lake powan (Coregonus clupeaformis) during the eutrophication and oligotrophication of Lake 226, the Experimental Lakes Area, Canada. Archiv für Hydrobiologie, Advances in Limnology 50:151-160.

Mookerji, N., C. Heller, H. J. Meng, H. R. Bürgi, and R. Müller. 1998. Diel and seasonal patterns of food intake and prey selection by Coregonus sp. in reoligotrophicated Lake Lucerne, Switzerland. Journal of Fish Biology 52:443-457.

Nilsson, N.-A. 1974. Food relationship of the fish community in the offshore region of Lake Vänern. Institute of Freshwater Research Drottningholm Report $17: 1-57$.

Northcote, T. G. 1988. Fish in the structure and function of freshwater ecosystems: a "top-down" view. Canadian Journal of Fisheries and Aquatic Sciences 45:361-379.

Nümann, W. 1959. Das Wachstum der Blaufelchen und seine Berechnung bei Erfassung aller Individuen der einzelnen Jahrgänge in Abhängigkeit von der Stärke 
des Jahrgangs, den jährlich variierenden Aussenfaktoren, der Eutrophierung und den regionalen Unterschieden des Sees. [The growth of pelagicspawning powan and its estimation by including all individuals in the individual year-classes along with the strength of the year-class, the annually varying external factors, eutrophication, and regional differences in the lake.] Archiv für Fischereiwissenschaft 10:5-20.

Paloheimo, J. E. 1974. Calculations of instantaneous birth rate. Limnology and Oceanography 19:692694.

Parrish, D. L., and F. J. Margraf. 1990. Interactions between white perch (Morone americana) and yellow perch (Perca flavescens) in Lake Erie as determined from feeding and growth. Canadian Journal of Fisheries and Aquatic Sciences 47:1779-1787.

Reckahn, J. A. 1992. More evidence of lamprey control as the initial factor in the rehabilitation of lake powan (Coregonus clupeaformis). Polish Archives of Hydrobiology 39:307-315.

Rösch, R. 2000. Gonadosomatic index (GSI) of female powan (Coregonus lavaretus) in Lake Constance. Limnologica 30:193-196.

Rudstam, L. G., F. P. Binkowski, and M. A. Miller. 1994. A bioenergetics model for analysis of food con- sumption patterns of bloater in Lake Michigan. Transactions of the American Fisheries Society 123: 344-357.

Saunders, P. A., K. G. Porter, and B. E. Taylor. 1999. Population dynamics of Daphnia spp. and implications for trophic interactions in a small, monomictic lake. Journal of Plankton Research 21: 1823-1845.

Straile, D. 1998. Biomass allocation and carbon flow in the pelagic food web of Lake Constance. Pages 545-563 in E. Bäuerle and U. Gaedke, editors. Lake Constance: characterization of an ecosystem in transition. Archiv für Hydrobiologie, Advances in Limnology 53, Stuttgart, Germany.

Straile, D., and W. Geller. 1998. Crustacean zooplankton in Lake Constance from 1920 to 1995: response to eutrophication and re-oligotrophication. Pages 255274 in E. Bäuerle and U. Gaedke, editors. Lake Constance: characterization of an ecosystem in transition. Archiv für Hydrobiologie, Advances in Limnology 53, Stuttgart, Germany.

Tolonen, A. 1999. Application of a bioenergetics model for analysis of growth and food consumption of subarctic powan Coregonus lavaretus (L.) in Lake Kilpisjärvi, Finnish Lapland. Hydrobiologia 390: 153-169. 